\title{
TRANSPARENCY, ACCOUNTABILITY AND PARTICIPATION IN LOCAL GOVERNMENTS: A COMPARATIVE STUDY OF SPANISH COUNCIL WEBSITES
}

Marta Rebolledo :: Rocío Zamora Medina :: Jordi Rodríguez-Virgili

IZVORNI ZNANSTVENI RAD / DOI: 10.20901/ms.7.14.5 / PRIMLJENO: 07.03.2016.

\begin{abstract}
Citizens' disaffection with political institutions has resulted in an ever more pronounced distancing between the represented and their representative democratic institutions, with a commensurate increase in citizens' initiatives aimed at obtaining a higher degree of participation in public life. The imbalance experienced by representative democracy in this respect accounts for the need to improve the way in which institutions communicate. This study aims to assess local communication in the regions of Murcia and Navarre by analysing the level of transparency of their institutional websites. The 41 indicators that underpin Mapa Infoparticip@ (www.mapainfoparticipa.com) in Spain are used to see what similarities and differences can be identified when applying the criteria of transparency and participation in these two single-province Autonomous Communities. The findings show a deficit in implementing norms of transparency. This fact affects the role these institutions play as sources of public information and citizen participation, and it appears in a clearer way in municipalities with a smaller population.
\end{abstract}

KEY WORDS

PUBLIC COMMUNICATION, TRANSPARENCY, ACCOUNTABILITY, PARTICIPATION, LOCAL GOVERNMENT

Authors note

Marta Rebolledo :: University of Navarra, School of Communication, Spain and Université Paris-Est, France :: mrebolledo@alumni.unav.es

Rocío Zamora Medina :: University of Murcia, Spain :: rzamoramedina@um.es Jordi Rodríguez-Virgili :: University of Navarra, School of Communication, Spain :: jrvirgili@unav.es

This research project was funded by the Spanish Ministry of Education and Science, under the project "Public Communication, transparency, accountability and participation in the local governments" (Ref: CSO2013-46997-R) (2014-2016). 


\section{INTRODUCTION}

Citizens' disaffection with public institutions has been increasing; initiatives have been developed by civil society to reflect this discontent, convey their message of protest and express their desire to participate in political decision-making. Given this changing and uncertain set of conditions faced by institutions as social entities that manage the assets and rights of citizens, communication is a key element in adapting to this new social environment. Communication is therefore more essential than ever in order for institutions to regain their credibility and citizens' trust (Norris, 2000). The management of transparency that fosters informed participation by citizens is an essential requirement in rehabilitating institutions (Bauhr and Grimes, 2014). With the approval of a transparency law on 28 November, 2013, Spain provides an interesting case study in order to assess the efforts of local governments in improving their relationship with citizens.

This local context is precisely the setting of choice for this research. The main objective of this study is to analyse how digital technologies are used on the websites of local councils, in other words, to study the resources, features and practices of online public communication by local councils. The choice of local institutions as an object of study is based on the fact that they are the closest to citizens and are strongly involved in their daily lives. They also enjoy a greater level of trust from citizens, compared to national institutions (Kim and Lee, 2012). This analysis will reveal how civic participation is facilitated (or weakened) by monitoring and evaluating the management of local governments.

The demand for transparency is a basic claim necessary to advance towards more participatory forms of democracy and to substantiate the act of participation itself. There are many organisations working in this direction, such as Transparency International, a non-governmental organisation founded in 1993 in order take a stance against political corruption, and is now present in over 100 countries. Other organisations determine the criteria and characteristics that information should have. Open Government Data and The Open Knowledge Foundation, for example, have defined the principles for government data to be considered open.

This study shows the results of research from the Research and Development (R\&D) project entitled "Public communication, transparency, accountability and participation in local government" (reference CSO2013-46997-R), a collaboration of several Spanish universities funded by the Spanish Ministry of Economy and Competitiveness within the National Programme for Research, Development and Innovation, included in the National Plan for Scientific and Technical Research and Innovation 2013-2016. This project seeks to examine communication in all local governments in Spain.

The project of which this study is part of, is in turn inspired by an earlier one entitled "Communication and Journalism for Citizen Participation in Monitoring and Evaluating the Management of Local Governments" (CSO2012-34687). This project used the Mapa Infoparticip@ platform (www.mapainfoparticipa.com), which shows how local public administrations make use of the Internet and new media to promote accountability and 
transparency. The mission of this new project is to supplement the work previously done and continue the coverage of the Mapa Infoparticip@ platform in 10 other Autonomous Communities, in order to capture a complete picture of the Spanish national territory. This will provide comparable information that can then enable a set of concrete proposals developed for the improvement of good governance and local public data. The ultimate goal is the promotion of good practices among political representatives, communications professionals and journalists.

The project is relevant because it addresses the public communication of local governments empirically and proactively, with a view to encouraging the promotion of transparency and the quality of information, as well as government accountability and the enhancement of public participation.

In this particular case, the websites of the local governments in the Autonomous Communities of Navarre and Murcia (both consisting of only one province, known as simple communities) have been taken as a case study. In total, our sample included 317 websites. The analysis was conducted before the municipal election of May 2015.

\section{ANALYTICAL FRAMEWORK}

There is a direct relationship between journalism, public communication and democracy (Rodriguez-Virgili et al., 2011), and between communication strategies and the preservation of power. Along these lines, Paul Starr noted that "one danger of reduced news coverage is to the integrity of government. It is not just a speculative proposition that corruption is more likely to flourish when those in power have less reason to fear exposure" (Starr, 2009: 28).

To the extent that the interests of the actors engaged in public communication are known and the results can be evaluated, the conditions of the democratic system are improved. The new technologies of the information society have given rise to a form of government that is more open, transparent and responsive to recipients, on the basis of a more democratic and less hierarchical society. A distancing from the principle of unilateral government thus emerges, in order to demand an alternative way of managing relationships and accountability. In this respect transparency is perceived as an ideal mechanism to replace the exclusive control of centralised government bodies (Chun et al., 2010).

New media have accelerated this accountability so that it is almost available in real time. In the case being discussed here, our interest is focused on the ability for citizens to influence local authorities and other local institutions through the intensive use of technology. This involves making actors look at themselves in the mirror in order to modify their behaviour. In the political sphere, communication policies study the legal and political conditions that affect the development of civil liberties. The doctrine of the Spanish Constitutional Court on freedom of information strongly advocates the special 
importance of freedom of information in democracy, as information and its availability conditions public opinion. In a state that recognises the rule of law and is responsible for the social and democratic rights of its citizens, public authorities must guarantee the right of citizens to know how the public authorities act. Citizens must be free to ask about whatever they deem appropriate and to form their own opinions within an environment where the public sector, the private sector, and the citizens are constantly interrelated. In an increasingly complex society, the exercise of freedom of expression requires more access to data and sources.

A number of studies have been previously conducted with regard to the transparency and accountability of governments (Alguacil Gómez, 2006; Guerrero, 2006; Labio Bernal, 2006; Molina Rodríguez-Navas, 2008; Reig, 2009; Villoria, 2001). In addition, under the umbrella of the project entitled "Communication and Journalism for Citizen Participation in Monitoring and Evaluating the Management of Local Government" (CSO2012-34687) mentioned above, findings and conclusions have also been published on the topic (Molina Rodríguez-Navas et al., 2011; Moreno Sardá et al., 2013a; Moreno Sardá et al., 2013b).

Our research examines local government websites in hope that by noting how they make government action transparent and accountable we can promote improvements in the information provided and thus advocate the right of access to information and transparency, based on the principle of actively making information public. This principle appears in the Law for Transparency, Access to Public Information and Good Governance, access to public information and good governance, approved by the Spanish Council of Ministers on 27 July, 2012.

The principle, which advocates actively making information public as currently drafted reads:

Information subject to transparency requirements shall be published on the relevant electronic sites and webpages in a manner that is clear, structured, and understandable to all stakeholders. Appropriate mechanisms shall be established to facilitate accessibility, interoperability, quality and the reuse of published information, as well as its identification and location. (BOE, 2013)

If enacted correctly, this principle could be instrumental in transforming political action. It involves the mandatory publication of valuable information and affects local councils, county councils, regional governments and the national government. It must be considered that the publication obligation includes not only administrative contracts, the distribution of grants and their subsequent criteria, but also any signed agreements, details of activities carried out, the list of assets owned by senior officials, and the status of various legislative projects and their legal amendments, among other items of a more basic information (government action plan, the biographies of public officials and the list of professionals employed by the council who have been freely appointed). In particular, the proposed project calls for public institutions to become sources of healthily transparent information, and to begin working on communication at the local level as a type of experimental laboratory. 
In addition, the set of practices employed by institutions aimed at bringing democratic usages to citizens are the foundations of future improvement in the management of public affairs. Transparency in public activities is a means of encouraging citizen participation in decision-making and in the management of relevant affairs, as well as reducing injustice and, ideally, corruption (Stasavage, 2003).

It seems of interest to investigate the potential that exists in social networks and other digital forms of online participation, as tools that extend the public sphere (Simelio and Molina Rodríguez-Navas, 2014). It is appropriate to consider what the current practices are (what is done) and what potential is consistent with added information and increased participation (what could be done).

In an increasingly complex society, the exercise of the freedom of expression requires more access to data and sources. This aspect is even better understood by taking the management of local communication as a starting point, since this close environment deals with and solves matters of everyday life, in contrast with national and global issues (Zamora, 2011).

The transparency project is already in the political, media and civic agenda. Therefore, a research project that links local public communication, accountability, management and participation is both relevant and necessary. It could represent a step forward to the extent that, thanks to public information, citizens can participate in public life and have the necessary knowledge to influence its development, prevent and control administrative inefficiencies, correct mistakes, denounce injustices, and establish deeper relationships within the local community.

\section{HYPOTHESIS}

As noted above, the websites of the local councils of two Spanish Autonomous Communities, Navarre and Murcia, both containing only one province, have been taken as the focus of our case study. The sample includes all of the municipalities of both regions, that is, 272 municipalities in Navarre and 45 in Murcia. In total, the sample size includes 317 local councils. The analysis was conducted before the local election held in May 2015.

This paper starts from a general hypothesis $(\mathrm{H} 1)$. The websites of Spanish local councils show deficiencies when accounting for the management carried out by the municipal governments. These deficiencies are reflected in several ways: there is a lack of relevant information (legislative projects, agreements and contracts signed, action plans); the data appearing on government websites is not well-explained and poorly conveyed to the citizens; the information presented is not neutral, accessible and reliable; and there is no tool devoted to interact with citizens. 
These insufficiencies affect the role these institutions play as sources of public information, sometimes hindering public debate and informed public participation, generating distrust among citizens.

Within this general hypothesis, we assume a second on $(\mathrm{H} 2)$ : the more populous municipalities will have a greater degree of transparency and encourage a more fluid relationship, thanks to the technologies used, than those with a smaller population, mainly due to the greater availability of resources. Moreover, an assumption has also been included that, in these two single-province regions, the model of local administration involved - Navarre is more decentralised, with a greater number of councils, while Murcia is more centralised, with fewer councils - can make a difference in terms of implementing the transparency and participation criteria identified.

\section{METHODOLOGY}

To test these hypotheses $(\mathrm{H} 1$ and $\mathrm{H} 2)$, we conducted a quantitative analysis of the presence/absence of a set of indicators that measure the level of transparency and participation offered by the websites of the local councils selected in the sample.

To evaluate the information provided by the websites, 41 indicators related to four main questions were used: who the political representatives are; how common resources are managed; how information is provided about their management; and what tools are published to facilitate public participation. The results of the analysis were introduced into a digital platform where they were automatically allocated a color according to their score on a numeric scale. These indicators are based on the Map of Good Practices of Local Public Communication. Some of the indicators used are also listed in the Transparency Index of local councils (Transparency International Spain, 2010).

The data were initially recorded in an Excel spreadsheet and then transferred to the platform's content management tool. Once the differences and similarities were identified, a comparative analysis of the information provided on these websites was carried out. The purpose was to gauge in which cases journalistic treatment was given (or not), so that complex information was made intelligible to the public; and to see in what aspects, according to the indicators used, there was a greater lack of information and transparency.

Some specific considerations must be mentioned in connection with the analysis of the websites. Firstly, to evaluate the information posted on the websites of local councils in agreement with the indicators, the official website of each local council was identified, considering that it may not be the name of the municipality, but a touristic information website. And secondly, some official websites may have been divided creating other webpages that could be defined as virtual offices or some functional equivalent. The data we assessed were considered basic information and therefore, should be available in a maximum of three clicks. 
In addition, it must be borne in mind that the data must be kept up to date. The website, once designed, set up and equipped with content, must have a process of constant updates. If this is not done properly, the information becomes obsolete, the links do not work and the opposite effect of the one desired when setting up a service of this type is achieved.

The indicators have not been designed so much to assess the transparency of management, but more to evaluate the provision of basic information, so that anyone can see who the political leaders of the local governments are and how they manage the common resources.

The 41 indicators, in turn, make up four thematic blocks: indicators aimed at identifying the composition of the council; indicators that provide information on how the administration and the local government operates; indicators linked to current information about the municipality, including their awareness of transparency; and indicators that provide public information about the local council and contact details.

\section{RESULTS}

In order to present the study's findings, the four blocks of indicators mentioned above will be analysed, based on an initial general assessment of performance against the indicators included in each block.

Before assessing the results, it is important to take into account the different distribution of municipalities according to size in of the each two cases. As shown in Table 1, in Navarre there is a large number of small boroughs with fewer than 1,000 inhabitants, while in Murcia medium-sized boroughs predominate, with an average number of inhabitants of approximately 20,000 .

Table 1. Navarre and Murcia population share of municipalities by size

\begin{tabular}{|lll}
\hline Population size class & $\begin{array}{l}\text { Autonomous Community } \\
\text { of Navarre }\end{array}$ & $\begin{array}{l}\text { Autonomous Community } \\
\text { of Murcia }\end{array}$ \\
\hline$<1,000$ inhabitants & $59.6 \%$ & $6.7 \%$ \\
$1,001-10,000$ inhabitants & $35.7 \%$ & $26.7 \%$ \\
$10,001-20,000$ inhabitants & $3.3 \%$ & $28.9 \%$ \\
$20,001-50,000$ inhabitants & $0.9 \%$ & $28.9 \%$ \\
$50,001-100,000$ inhabitants & $0 \%$ & $4.4 \%$ \\
$>100,000$ inhabitants & $0.5 \%$ & $4.4 \%$ \\
\hline
\end{tabular}

An important initial result is seen in the case of the total sample from Navarre (272 municipalities), about $22 \%$ of the sample (59 municipalities) had no website at all at the time of the study. Most of these municipalities are the smallest in terms of population size. 
This contrasts with the Community of Murcia, in which $100 \%$ of the municipalities had a local council website.

\section{Indicators of transparency related to the information on the composition of the council}

Overall, the analysis identified significant shortcomings in both regions in terms of the basic type of information for any local government website, such as the composition of the government team. In most local council websites there was hardly any basic information that any citizen might need, such as who their local representatives were, or what their professional training was. Even the information provided on the website about the most visible face of the local political administration, the mayor of the city or town was insufficient.

As data shows, although this pattern was repeated in both of the regions included in the analysis, some differences were found. In Murcia, $75.6 \%$ of the municipalities did include some information on the mayor, such as their full name and/or a photograph. This contrasts with Navarre, where $77.9 \%$ of the local council websites did not include this information. However, the biographical data of the mayor was available in a very few cases in both regions (only in $1.4 \%$ of cases of Navarre and in $17.8 \%$ in Murcia). This lack of information means that citizens are deprived of the knowledge about the professional or political path of their highest representative in their village, town or city.

Information was also sparse on the rest of the representatives of the local administration, with both names and photographs lacking, and considerable differences between the two cases under study. In Navarre, in only $1.9 \%$ of the cases was information offered on both the government representatives and on those who make up the opposition, while in Murcia almost one in two councils identified the government representatives, although only $24 \%$ of the available websites did the same for members of the opposition.

The fact that this information and the biography of each of those political representatives in the local government was only offered in $0.9 \%$ of the cases in Navarre and $13.3 \%$ in Murcia, and information about members of the opposition was only available in $0.9 \%$ of the cases in Navarre and $6.7 \%$ in Murcia, clearly breaks the link between representatives and those they represent.

\section{Transparency indicators related to information about the local government and administration}

Another key issue in relation to transparency has to do with how collective resources are managed. While there are legal obligations whereby certain procedures and decisions are required to be public, there was a considerable information deficit in both regions.

Specifically, as shown in Table 2, information on the jurisdictional capacities of the governing bodies (plenary council meeting, council board and advisory committees) 
appeared in only $4.7 \%$ of the Navarre municipalities, with a significantly higher proportion in the case of Murcia, where it was available in $40 \%$ of the cases.

Information on the composition of these governing bodies was slightly more widely available in both communities, with less than half of the municipalities making it available (45\% in Navarre and $37.8 \%$ in Murcia). However, there was little information about the work schedule of these governing bodies, as this data appeared in only $5.2 \%$ of the cases for local governments in Navarre and in 2.2\% for local governments in Murcia. This lack of transparency prevents citizens from exercising real control over the work of their political representatives.

In regards to plenary council meetings, an activity that attracts more media attention locally, we found that, contrary to what might be thought, the agenda for these meetings was not generally available on municipal websites (only in $3.8 \%$ of the cases in Navarre and in $15.6 \%$ of the cases in Murcia). The information provided was restricted to the minutes of the plenary sessions at the most, and even then the minutes were not uploaded in most of the examined municipalities (27.7\% in Navarre and 33.3\% in Murcia).

The plenary sessions are the fullest expression of the local government as a democratic institution, and this lack of information undoubtedly makes it unlikely for the municipality's citizens to be aware of the decisions made and resolutions adopted by the local government, which were also rarely published in either case $(4.2 \%$ in Navarre and $13.3 \%$ in Murcia).

In every municipality there are a number of plans that affect different local government jurisdictional capacities and should also follow a criteria for transparency. This applies, for example, to the Government Plan (known by its initials in Spanish as ' $P G$ ') and the Municipal Action Plan (known by its initials in Spanish as 'MAP') and/or the Municipal Strategic Plan. Our analysis shows that only $3.8 \%$ of the local government websites in Navarre and only $6.7 \%$ of those in Murcia provided information about these plans. Information about the Urban Development Plan (known by its initials in Spanish as 'POUM') and other rules concerning urban planning was similar. In this case, we identified some significant differences in terms of the information published about this plan by the local governments in Navarre (only 12.7\%) compared with those in Murcia (57.8\%), mainly justified by the importance of the urban planning and the construction sector in the latter.

Information about other local government plans that may be of interest to citizens, such as Agenda 21, Youth, Participation, etc. was also more commonly found in Murcia (35.6\%) than in Navarre (9.9\%).

But undoubtedly the indicator that stood out as far as citizens are concerned was the list of local government posts and the salaries paid. It is noteworthy that in Navarre, only $0.5 \%$ of websites provided this information, with something similar in Murcia, where only $8.9 \%$ of the total websites providing this information. Another very interesting finding from a social perspective is the data on the remuneration of elected officials. 
The information published online in this regard remained problematic, as only $1.9 \%$ of Navarre's local governments and $8.9 \%$ of those in Murcia surprisingly made this data public at the time of our analysis.

Something else that citizens need to know are the ordinances or regulations issued by the highest authority of a metropolitan district or a local council that are valid within the relevant metropolitan district or village/town/city. In this respect, while most municipalities of Murcia provided public information concerning ordinances (75.6\%), in Navarre the percentage dropped to $37.1 \%$.

Finally, the information provided about the municipal budget was of crucial importance. According to the data, this information is severely lacking and is absent from the majority of the local government websites in Navarre (23.5\% of cases) and Murcia (42.2\%). This is compounded by the fact that, when it comes to specifying the level of implementation of the budget, this information is fairly opaque in the municipality websites in Navarre, since it appears in only $1.9 \%$ of cases (compared with $28.9 \%$ in Murcia).

Other economic management reports, such as the reports on the annual general accounts and the financial management report, rarely appear on local council websites (in $2.8 \%$ of cases in Navarre and in $13.3 \%$ of cases in Murcia).

Table 2. Transparency concerning the management of collective resources in Navarre and Murcia

\begin{tabular}{|c|c|c|}
\hline Compliance with transparency criteria & Navarre & Murcia \\
\hline Information on the government bodies' jurisdictional capacities & $4.7 \%$ & $40 \%$ \\
\hline Information on the composition of government bodies & $45.1 \%$ & $37.8 \%$ \\
\hline Information about the work schedule of government bodies & $5.2 \%$ & $2.2 \%$ \\
\hline $\begin{array}{l}\text { Publication of notices for meetings (including the agendas) } \\
\text { prior to holding plenary sessions }\end{array}$ & $3.8 \%$ & $15.6 \%$ \\
\hline Publication of plenary sessions' minutes & $27.7 \%$ & $33.3 \%$ \\
\hline Publication of local government or council board resolutions & $4.2 \%$ & $13.3 \%$ \\
\hline $\begin{array}{l}\text { Information about the Government Plan, Municipal Action } \\
\text { Plan and/or Strategic Plan }\end{array}$ & $3.8 \%$ & $6.7 \%$ \\
\hline $\begin{array}{l}\text { Information about the Urban Development Plan and other } \\
\text { urban planning rules }\end{array}$ & $12.7 \%$ & $57.8 \%$ \\
\hline $\begin{array}{l}\text { Information about other local government plans: } \\
\text { Agenda21, Youth, Participation, etc. }\end{array}$ & $9.9 \%$ & $35.6 \%$ \\
\hline Publication of the salaries of local government posts, by category & $0.5 \%$ & $8.9 \%$ \\
\hline Publication of the salaries of elected officials & $1.9 \%$ & $8.9 \%$ \\
\hline Publication of council ordinances & $37.1 \%$ & $75.6 \%$ \\
\hline Publication of council budget & $23.5 \%$ & $42.2 \%$ \\
\hline $\begin{array}{l}\text { Publication of information about the implementation } \\
\text { of the budget }\end{array}$ & $1.9 \%$ & $28.9 \%$ \\
\hline $\begin{array}{l}\text { Publication of the reports on the annual general accounts } \\
\text { and the financial management report }\end{array}$ & $2.8 \%$ & $13.3 \%$ \\
\hline
\end{tabular}




\section{Indicators of transparency related to information about current issues in local government and awareness of transparency}

The third block of results presented here concerns how the councils in the study provide information about the management of collective resources. In general, some significant differences were identified between the regions. The websites of Murcia's local councils typically include news as a standard practice $(93.3 \%)$ more often than the websites in Navarre's local councils (38\%). Many of these pieces of news have to do with the activities of government's members level of accountability (46.7\% in Murcia, and only $9.4 \%$ in Navarre) and, to a lesser extent, with the activities of the members of the opposition in connection with the monitoring of the local government's management (only $6.7 \%$ of cases in Murcia and $0.9 \%$ in Navarre).

Other valuable information of public interest is the granting of contracts and concessions signed by the local authorities with other institutions, companies or individuals, as well as the contractor's profile. While this information is scarcely present on council websites in Navarre (5.6\%), it has a much greater presence and visibility on local government websites in Murcia ( $86.7 \%$ of cases).

Finally, a general lack of awareness of transparency issues was shown by local governments' websites in both Autonomous Communities. Only $6.7 \%$ of the councils websites in Murcia, and $0.9 \%$ in Navarre, show any kind of explicit support for the Decalogue for Good Practice for Local Public Communication (Decálogo de Buenas Prácticas de la Comunicación Local Pública), a similar proportion to that of councils that manage to make the referred Principles publicly available, or anything related to it on their webpages (0.9\% in Navarre and $4.4 \%$ in Murcia). Despite the guidelines stipulated under Law 19/2013, on transparency, public access to information and good governance, it seems that local governments have not yet felt social pressure and do not show an awareness about such issues.

\section{Transparency indicators related to public information about the local government and contact details}

This fourth and last section examines what tools are offered by local council websites to promote citizen participation and democratic control. Table 3 shows the presence of relevant information (in percentages) shown for each of the applicable indicators.

The majority of the councils have information relevant to the status of the relevant village/town/city on their websites (73.2\% in Navarre and $53.3 \%$ in Murcia), as well as its history (80.3\% in Navarre and $80 \%$ in Murcia). This kind of information, shown on the local council website turns it, somewhat into a tourist portal for the relevant municipality.

However, information that would assist citizens in contacting their representatives or members of the opposition is less often found (only in 3.8\% of Navarre's websites, compared to $26.7 \%$ of Murcia's websites for representatives, and $1.9 \%$ compared to $11.1 \%$ for members of the opposition). This limits any kind of direct interaction between citizens and local politicians. 
Another way that a citizen could interact with the local institution is through their social media profiles. The transparency criteria in this regard are not met either, considering that only $17.8 \%$ of Navarre's councils offered access to this profile on their website, compared to almost half of Murcia's councils that did provide this data.

With regard to the real possibilities of exercising citizen participation in local decisionmaking, most local governments did not include in their websites any regulations on civic participation (only $2.3 \%$ of cases in Navarre, as opposed to $20 \%$ in Murcia). It was also unusual to find other mechanisms for civic participation, such as regional committees, city/town committees, sector committees, etc. (only $1.9 \%$ in Navarre versus $6.7 \%$ in Murcia).

There are other types of practical information that are usually present in municipal websites, such as information about the schedule of activities, sometimes clearly (with this being the case for $66.7 \%$ of the council websites in Murcia) and other times (as in the case of Navarre, with it being available in only $26.8 \%$ of cases) only in certain municipalities. Something similar applies to information about the directory of council bodies, which also tends to be very helpful for many citizens (present in $71.1 \%$ of Murcia council webpages as opposed to $31.5 \%$ council webpages in Navarre).

Through their website, councils have an opportunity to offer participation tools for the preparation and/or monitoring of the Government Plan, the Municipal Action Plan and/ or the Strategic Plan. However, this is quite anomalous in light of the results of our study, as it happens in only $1.4 \%$ of the cases in Navarre and $2.2 \%$ of the cases in Murcia. When it comes to civic participation in the preparation of the municipal budget, local government websites are also rather opaque: only $3.8 \%$ of Navarre councils have this option available, as compared to $4.4 \%$ of Murcia councils.

Finally, every website should include a section to receive criticism or suggestions from the public, and should also provide the details to contact the institution through the communications manager. Although it seems that this first criterion of transparency is met by the vast majority of councils in both Navarre and Murcia (55.4\% in Navarre and $80 \%$ in Murcia), the options available to directly contact the communication managers for each local council could be much improved. This has a negative impact not only on the relationship between citizens and the institution, but above all, in terms of the potential contact by the media with local, public institutions.

Table 3. Transparency regarding the management of collective resources in Navarre and Murcia

\begin{tabular}{lll} 
Compliance with transparency criteria & Navarre & Murcia \\
\hline $\begin{array}{l}\text { Information on the village/town/city location: territorial area, } \\
\text { population size, social diversity, etc. }\end{array}$ & $73.2 \%$ & $53.3 \%$ \\
$\begin{array}{l}\text { Historical information about the village/town/city } \\
\begin{array}{l}\text { Information about the email addresses of members } \\
\text { of the local government }\end{array}\end{array}$ & $80.3 \%$ & $80 \%$ \\
\hline
\end{tabular}




\begin{tabular}{|c|c|c|}
\hline Compliance with transparency criteria & Navarre & Murcia \\
\hline $\begin{array}{l}\text { Information about the email addresses of members } \\
\text { of the opposition }\end{array}$ & $1.9 \%$ & $11.1 \%$ \\
\hline Information about accessing the council's social networks & $17.8 \%$ & $48.9 \%$ \\
\hline Information about regulations concerning citizen participation & $2.3 \%$ & $20 \%$ \\
\hline $\begin{array}{l}\text { Information about other participation mechanisms: regional } \\
\text { committees, village/town/city committees, } \\
\text { sector-related committees, etc. }\end{array}$ & $1.9 \%$ & $6.7 \%$ \\
\hline Information/agenda about council and citizens' activities & $26.8 \%$ & $66.7 \%$ \\
\hline Information/directory of council bodies & $31.5 \%$ & $71.1 \%$ \\
\hline $\begin{array}{l}\text { Participation tools for the preparation and/or monitoring of the } \\
\text { Government Plan, Municipal Action Plan and/or Strategic Plan }\end{array}$ & $1.4 \%$ & $2.2 \%$ \\
\hline $\begin{array}{l}\text { Participation tools for the preparation and/or monitoring of the } \\
\text { budget or other council plans }\end{array}$ & $3.8 \%$ & $4.4 \%$ \\
\hline $\begin{array}{l}\text { Tools to report incidents about the public thoroughfare, } \\
\text { complaints or suggestions }\end{array}$ & $55.4 \%$ & $80 \%$ \\
\hline $\begin{array}{l}\text { Publication of the contact information for the local council's Press, } \\
\text { Information and/or Communications manager }\end{array}$ & $0.5 \%$ & $15.6 \%$ \\
\hline
\end{tabular}

\section{DISCUSSION AND CONCLUSIONS}

In this research we have presented some proposals on the theoretical and empirical aspects of transparency at the local government level, and the first overall results regarding two single-province regions (Autonomous Communities) in Spain.

From this analysis of 317 websites of local councils in Murcia and Navarre, the initial general hypothesis has been confirmed. At the time of the study (May 2015) it was estimated that there was a deficit in the implementation of the Law on transparency, access to public information and good governance, published by the Spanish Government on 9/12/13, which provided a broad framework for local administrations to update and improve their public information mechanisms. This need to improve transparency affects the role these institutions play as sources of public information, since they sometimes hinder public debate and citizen participation. Certainly, there is ample room for improvement and little time for it, because Law 19/2013 requires Autonomous Communities and local government bodies to adapt and comply before the end of December 2015.

Another consideration to be taken into account is the different organisation of the municipal map of the two communities. The sample included all the local councils, but Navarre, with a population size of 640,154 in 2014, has 272 municipalities; while Murcia, with more than twice the population $(1,466,818)$ has 45 municipalities. This difference in the size of municipalities highlights an imbalance that makes the two difficult to compare and, therefore, the differences in the implementation of the transparency criteria should be considered in the light of this situation. Establishing minimum population sizes (for example, 20,000 or 10,000 ) was not viable, because this would not reach $5 \%$ of Navarre 
municipalities. Perhaps that barrier could have been established at a minimum of 1,000, but almost $60 \%$ of Navarre's councils and only $6.7 \%$ of those from Murcia would fall outside of this limit. As the data shows, those municipalities with the largest population have a greater degree of transparency and encourage a more fluid relationship than those with a smaller population thanks to the technologies they offer, mainly due to the provision of more resources in the larger areas and the channelling of information by other analogue channels in the smaller ones.

With regard to the four main questions,

(1) In terms of the transparency indicators linked to information about the composition of the local government, it has been ascertained there is a serious problem for citizens to have access to information about the composition of councils and the professional and/or educational merits of the people who occupy posts in the local councils in both Autonomous Communities. The level of basic data provided by any council website about the composition of the team that made up the local government (including the opposition), in order for citizens to know who their political representatives were, did not reach $50 \%$ of the set criteria (50\%).

(2) Concerning the transparency indicators related to information about the local government and administration, there are clear differences between the Navarre and Murcia municipalities. In both cases there was a remarkable lack of information available, even though there are legal obligations in place for certain procedures and decisions to be made public. This opacity seems particularly serious considering the lack of information on plenary meetings, Government Plans, Municipal Action Plans and the municipal budget. Still, the situation of the local authority websites in Murcia gives less cause for concern and provides more information than those in Navarre. Such is the case of data on the Urban Development Plan, which, perhaps due to the importance of the urban planning sector, appears in $57 \%$ of council websites in Murcia, in contrast with $12.7 \%$ in Navarre.

(3) Regarding transparency indicators linked to information provided about the local government current affairs and awareness of transparency, significant differences were also identified between the two regions. Local government websites in Murcia typically included news as standard practice more often (93.3\%) than those in Navarre (38\%). But much of this information referred to members of the local government, and rarely included news about the activities of members of the opposition related to the monitoring of government management (only in $6.7 \%$ of the cases in Murcia and in $0.9 \%$ in Navarre). Therefore, it seems that local authority information is intended to give visibility to the activities of the local government in power, and not perceived as a local council for all citizens, with useful information that covers all of the parties.

(4) And lastly, concerning the indicators of transparency related to the councils' public information and contact details, much better scores were obtained by websites, but only in terms of their use as dissemination channels. That is, on the indicators regarding location, history and local activities they scored well, but on those to do with participation or which allowed interactivity, such as email addresses, social networks and regulations 
for citizen participation, much worse scores were obtained. Consequently, local council websites were perceived as tourism portals for the village/town/city, with little ability for interaction. Only the first criterion of transparency, which is to include a section for criticism or suggestions from the public, as well as offering information to contact the institution through the communications manager, was met by the vast majority of local council websites, both in Navarre and Murcia (55.4\% in Navarre and $80 \%$ in Murcia).

In short, there are some relevant implications from this first look at the websites of the local governments in Murcia and Navarre that point to deficiencies in terms of accounting for the management carried out by local authorities. The websites of the local councils analysed did not offer, in general terms, the minimum resources necessary to promote informed citizen participation. We part from the idea that information is a fundamental right for the proper functioning of democracy. Citizens, in order to evaluate how their political representatives manage collective resources, contribute to public debate and make decisions based on solid criteria, need information supplied by transparent, high-quality sources. Just as there are two sides to every coin, for every right there is a responsibility. In this case, politicians and administrators are required to provide information that is both complete and trustworthy. Today, the Internet eases this task of providing information and enabling participation, as it reduces the limitations of space and time. But the information available from local authorities must meet a set of standards, because informed political participation demands criteria for managing transparency. For future research, other Spanish regions should be included in the sample in order to get an overall national view of the transparency level in local structures.

\section{References}

>Alguacil Gómez, Julio (2006) Los desafíos del nuevo poder local: ¿hacia una estrategia relacional y participativa en el gobierno de la ciudad? [The Challenges of the New Local Power: Towards a Relational and Participatory Approach in City Government?], pp. 9-47 in Alguacil Gómez, Julio (ed.) Poder local y participación democrática [Local Power and Democratic Participation]. Barcelona: El Viejo Topo.

>Bauhr, Monika and Grimes, Marcia (2014) Indignation or Resignation: The Implications of Transparency for Societal Accountability. Governance 27 (2): 291-320. DOI: 10.1111/gove.12033. >BOE Boletín Oficial del Estado (2013) Ley 19/2013, de 9 de diciembre, de transparencia, acceso a la información pública y buen gobierno [Law 19/2013, of 9 December, Transparency, Access to Public Information and Good Governance]. https://www.boe.es/boe/dias/2013/12/10/pdfs/ BOE-A-2013-12887.pdf (10.09.2015).

>Chun, Soon Ae, Shulman, Stuart, Sandoval, Rodrigo and Hovy, Eduard (2010) Government 2.0: Making Connections between Citizens, Data and Government. Information Polity: The International Journal of Government \& Democracy in the Information Age 15: 1-9.

$>$ Guerrero, Enrique (2006) Responsabilidad y control: rendición de cuentas del Gobierno [Responsibility and Control: Government Accountability], pp. 165-178 in Martínez, Antonia (ed.) Representación y calidad de la democracia en España [Representation and Quality of Democracy in Spain]. Madrid: Tecnos.

>Kim, Soonhee and Lee, Jooho (2012) E-participation, Transparency, and Trust in Local Government. Public Administration Review 72 (6): 819-828. DOI: 10.1111/j.1540-6210.2012.02593.x.

>Labio Bernal, Aurora (2006) Comunicación, periodismo y control informativo [Communication, Journalism and Information Control]. Barcelona: Anthropos. 
>Molina Rodríguez-Navas, Pedro (2008) Ciberperiodismo e interactividad: entre la participación y la apariencia [Ciberjournalism and Interactivity: Between Participation and Appearance]. Anàlisi. Quaderns de comunicació i cultura 36: 175-182.

>Molina Rodríguez-Navas, Pedro, Corcoy Rius, Marta and Marín Ochoa, Beatriz (2011) Herramientas periodísticas en red para la información, seguimiento y evaluación de la acción de los gobiernos locales. Aplicación a actuaciones para la equidad de género en proyectos de mejora de barrios en Cataluña [Journalistic Networking Tools for Information, Monitoring and Evaluation of the Action of Local Governments. Application to Actions for Gender Equity in Projects for Improving Neighborhoods in Catalonia]. Revista F@ro 14. http://www.revistafaro.cl/index.php/Faro/article/ view/43/30 (01.09.2015).

>Moreno Sardà, Amparo, Molina Rodríguez-Navas, Pedro and Corcoy Rius, Marta (2013a) La información de las administraciones públicas locales. Las webs de los ayuntamientos de Cataluña [The Information from Local Government. The Websites of the Municipalities of Catalonia]. Revista Latina de Comunicación Social 68: 502-528.

>Moreno Sardà, Amparo, Molina Rodríguez-Navas, Pedro, Corcoy Rius, Marta, Aguilar Pérez, Antonio and Borràs Farran, Miguel (2013b) Infoparticip@: periodismo para la participación ciudadana en el control democrático. Criterios, metodologías y herramientas [Infoparticip@: Journalism for Citizen Participation in the Democratic Control. Criteria, Methodologies and Tools]. Estudios sobre el mensaje periodístico 19 (2): 783-803.

$>$ Norris, Pippa (2000) A Virtuous Circle: Political Communications in Postindustrial Societies. Cambridge: Cambridge University Press. DOI: 10.1017/CBO9780511609343.015.

$>$ Reig, Ramón (2009) Bases teóricas y documentales para el estudio de la Estructura de la información y el análisis estructural de los mensajes [Theoretical and Documentary Basis for the Study of Information Structure and Structural Analysis of Messages]. Estudios sobre el Mensaje Periodístico 15: 385-407.

>Rodríguez-Virgili, Jordi, López-Escobar, Esteban and Tolsá, Antonio (2011) Media Use and Public Perception of Politicians, Politics and Political Parties. Communication \& Society 24 (2): 7-40.

$>$ Simelio, Nuria and Molina Rodríguez-Navas, Pedro (2014) Comunicación pública y participación ciudadana. El uso de Twitter en los ayuntamientos de Cataluña [Public Communication and Citizen Participation. The Use of Twitter in the Municipalities of Catalonia]. Historia y Comunicación Social 19: 479-490.

$>$ Starr, Paul (2009) Goodbye to the Age of Newspapers (Hello to a New Era of Corruption). The New Republic 4: 28-35.

$>$ Stasavage, David (2003) Transparency, Democratic Accountability and the Economic Consequences of Monetary Institutions. American Journal of Political Science 47: 389-402. DOI: 10.1111/1540-5907.00028.

$>$ Transparency International Spain (2010) Índice de Transparencia de los Ayuntamientos [Councils Transparency Index]. http://webantigua.transparencia.org.es/ita_2010/metodologia_utlizada_en_ el_ita_2010.pdf (05.10.2015).

$>$ Villoria, Manuel (2011) La rendición de cuentas en la democracia [Accountability in Democracy]. Temas para el debate 204: 32-34.

>Zamora Medina, Rocío (ed.) (2011) Claves para gestionar la comunicación política local [Keys to Managing Local Political Communication]. Zamora: Comunicación Social Ediciones y Publicaciones. 


\section{TRANSPARENTNOST, ODGOVORNOST I PARTICIPACIJA U TIJELIMA LOKALNE VLASTI: KOMPARATIVNA ANALIZA MREŽNIH STRANICA ŠPANJOLSKIIH VIJEĆA}

Marta Rebolledo :: Rocío Zamora Medina :: Jordi Rodríguez-Virgili

SAŽETAK Nezadovoljstvo građana političkim institucijama rezultiralo je sve izraženijim udaljavanjem demokratskih institucija od građana koje one zastupaju, ali i proporcionalnim porastom građanskih inicijativa usmjerenih prema zadobivanju većeg stupnja participacije u javnom životu. Zbog neravnoteže koja sejavlja u okviru predstavničke demokracije pojavila se potreba za poboljšanjem načina na koji institucije komuniciraju. Cilj je ovoga istraživanja ocijeniti lokalnu komunikaciju u regijama Murcia i Navarre kroz analizu razine transparentnosti mrežnih stranica njihovih institucija. Primijenit će se ukupno 41 indikator, temeljen na španjolskoj platformi Mapa Infoparticip@ (www.mapainfoparticipa.com), kako bi se u te dvije autonomne zajednice, koje imaju svaka po jednu provinciju, utvrdile sličnosti i razlike na temelju kriterija transparentnosti i participacije. Rezultati istraživanja pokazuju deficit u implementaciji normativa transparentnosti, što utječe na ulogu tih institucija kao izvora javnih informacija, kao i na građansku participaciju, što je osobito vidljivo u općinama s manjim brojem stanovništva.

KLJUČNE RIJEČI

JAVNA KOMUNIKACIJA, TRANSPARENTNOST, ODGOVORNOST, PARTICIPACIJA, LOKALNA VLAST

Bilješka o autorima

Marta Rebolledo :: Sveučilište u Navarri, Facultad de Comunicación, Španjolska i Université Paris-Est, Francuska :: mrebolledo@alumni.unav.es

Rocío Zamora Medina :: Sveučilište Murcia, Španjolska :: rzamoramedina@um.es Jordi Rodríguez-Virgili :: Sveučilište u Navarri, Facultad de Comunicación, Španjolska :: jrvirgili@unav.es 